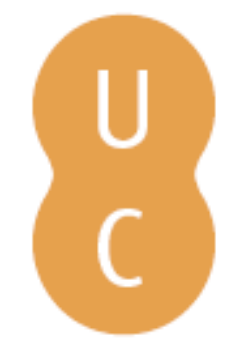

\title{
nommalina
}

\section{Representações do plano de educação popular e da campanha nacional de educação de adultos no ensino normal primário de Coimbra}

\author{
Autor(es): $\quad$ Ferreira, António Gomes; Mota, Luís \\ Publicado por: Imprensa da Universidade de Coimbra \\ URL \\ persistente: URI:http://hdl.handle.net/10316.2/31275 \\ DOI: $\quad$ DOI:http://dx.doi.org/10.14195/978-989-26-0228-8_15 \\ Accessed : $\quad$ 26-Apr-2023 15:02:47
}

A navegação consulta e descarregamento dos títulos inseridos nas Bibliotecas Digitais UC Digitalis, UC Pombalina e UC Impactum, pressupõem a aceitação plena e sem reservas dos Termos e Condições de Uso destas Bibliotecas Digitais, disponíveis em https://digitalis.uc.pt/pt-pt/termos.

Conforme exposto nos referidos Termos e Condições de Uso, o descarregamento de títulos de acesso restrito requer uma licença válida de autorização devendo o utilizador aceder ao(s) documento(s) a partir de um endereço de IP da instituição detentora da supramencionada licença.

Ao utilizador é apenas permitido o descarregamento para uso pessoal, pelo que o emprego do(s) título(s) descarregado(s) para outro fim, designadamente comercial, carece de autorização do respetivo autor ou editor da obra.

Na medida em que todas as obras da UC Digitalis se encontram protegidas pelo Código do Direito de Autor e Direitos Conexos e demais legislação aplicável, toda a cópia, parcial ou total, deste documento, nos casos em que é legalmente admitida, deverá conter ou fazer-se acompanhar por este aviso.

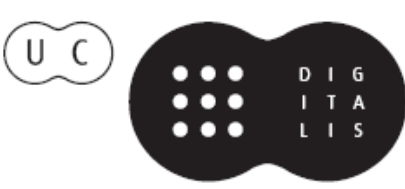




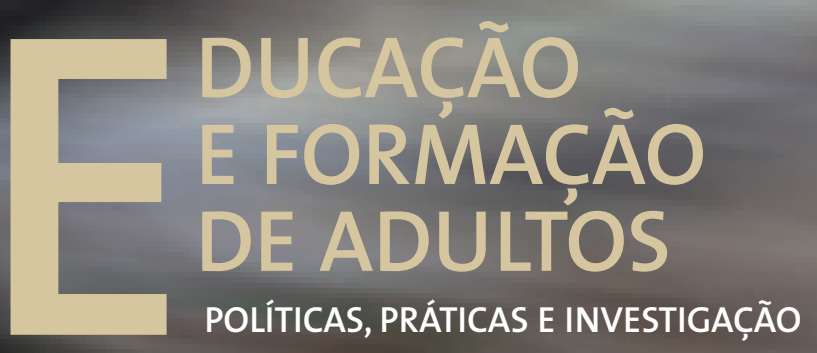

Luís Alcoforado • Joaquim Armando G. Ferreira António Gomes Ferreira • Margarida Pedroso de Lima Cristina Vieira • Albertina L. Oliveira • Sónia Mairos Ferreira 


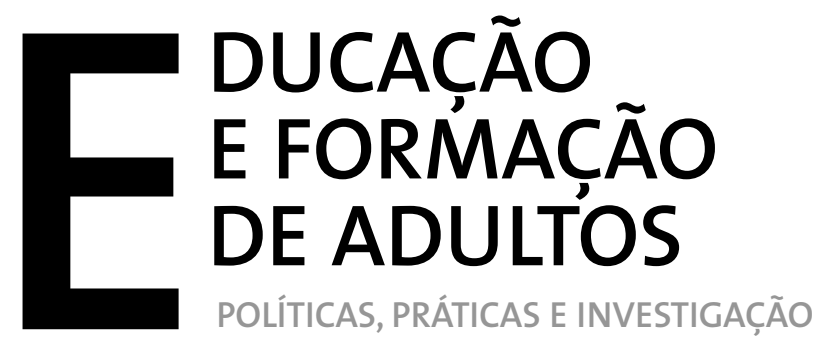

Luís Alcoforado • Joaquim Armando G. Ferreira António Gomes Ferreira - Margarida Pedroso de Lima Cristina Vieira • Albertina L. Oliveira • Sónia Mairos Ferreira 
EDIÇÃo

Imprensa da Universidade de Coimbra

URL: http://www.uc.pt/imprensa_uc

Vendas online: http://www.livrariadaimprensa.com

CONCEPÇÃO GRÁFICA

António Barros

Pré-Impressáo

SerSilito-Empresa Gráfica, Lda

EXECUÇÃo GRÁFICA

SerSilito-Empresa Gráfica, Lda

ISBN

978-989-26-0136-6

DePósito LEgaL

$340309 / 12$ 



\title{
Representaçóees do Plano de Educação Popular e da Campanha Nacional de Educação de Adultos no Ensino Normal Primário de Coimbra
}

\author{
António Gomes Ferreira \\ Universidade de Coimbra
}

Luís Mota

Escola Superior de Educação de Coimbra

As representaçóes construídas por professores e alunos da Escola do Magistério Primário de Coimbra sobre o Plano de Educação Popular e a Campanha Nacional de Educação de Adultos foram o ponto de partida para a nossa análise. A justificaçáo para uma abordagem do esforço de elevação dos níveis de escolaridade da população adulta pelo viés das representaçóes elaboradas no âmbito do ensino normal adveio do apelo do interior da Campanha e por iniciativa do seu primeiro responsável, o subsecretário de Estado da Educação Nacional. De acordo $\operatorname{com} A$ Campanha, no seu número de Agosto e Setembro de 1954, em reunião com a presença de «todos os directores das Escolas do Magistério Primário», do "Presidente do Júri único dos Exames de Estado» nas referidas escolas e do "chefe da Secção Pedagógica da Direcção-Geral do Ensino Primário», presidida pelo próprio Henrique Veiga de Macedo, foi analisada a possibilidade, e a forma, de intervençáo das escolas do magistério primário no Plano de Educação Popular. Foram estudadas áreas, em que seria expectável a sua intervenção, nomeadamente, no apoio à «execução do despacho sobre a missão das escolas primárias e dos cursos de adultos nos meios rurais», através da criação, na oferta de formação, de cursos especiais sobre a vida no campo, a possibilidade de cooperaçáo com a Campanha Nacional de Educação de Adultos e, no sentido de acautelar «o aspecto pedagógico da Campanha», considerou-se desejável que, no quadro das escolas, se aprofundasse o «estudo e experiências pedagógicas sobre o ensino e educação dos adolescentes e adultos» (1954, p. vi). Uma questão de partida emergiu neste quadro, como viram os alunos da Escola do Magistério Primário de Coimbra, futuros professores do ensino primário, a iniciativa governamental? Qual a sua perspectiva face ao analfabetismo e aos analfabetos? E qual o posicionamento dos seus professores? Num quadro mais amplo, qual o contributo que a Escola do Magistério Primário de Coimbra deu para o Plano de Educação Popular face ao desafio/orientaçóes que acabámos de apresentar?

Para a construção de uma grelha de leitura das representações de alunos e professores, analisámos o periódico Rumo, da responsabilidade dos alunos da Escola do Magistério Primário de Coimbra que asseguravam a respectiva direcção, redacção e administração. A publicação conheceu dois períodos de existência, o primeiro, entre 21 de Janeiro de 1949 e 15 de Julho de 1957 e, um segundo, entre 1 de Dezembro de 1959 e Fevereiro de 1969, teve quatro subtítulos e foi quinzenário e mensário. Nos quatro anos que compulsámos, e que coincidem com os anos da Campanha, desde a iniciativa legislativa até ao seu encerramento, de 1952 a 1956, intitulava-se Rumo, Quinzenário dos alunos da Escola do Magistério Primário de Coimbra, sendo que analisámos cerca de meia centena de artigos e notícias que, genericamente, se debruçavam especificamente sobre o Plano de Educação Popular ou afloravam a temática a partir da sua correlação com outro(s) assunto(s). 
Para além deste jornal, realizámos uma consulta exaustiva aos jornais regionais então existentes, o Correio de Coimbra, O Despertar e o Diário de Coimbra, este último, diário e os restantes, semanários, o que nos permitiu aferir do desenvolvimento dos cursos de educação de adultos e do desenrolar da Campanha Nacional de Educação de Adultos, do desencadear de actividades, acçóes e iniciativas no distrito, bem como, tomar conhecimento das personalidades e instituiçóes envolvidas.

A imprensa regional fez eco da realização de um Curso de Educadores de Adultos, na Escola do Magistério Primário de Coimbra, com inscriçóes que decorreram na secretaria da referida escola ou na direcção escolar. Desde finais de Novembro a 4 de Dezembro de 1953, sucessivas notícias nos vão dando conta da realização do curso, que teve direito a sessão solene de abertura, ocorrida a 3 de Dezembro de 1953, no Salão Nobre da União de Grémio dos Lojistas do Distrito de Coimbra, denunciando, de algum modo, o envolvimento da estrutura corporativa no Plano de Educação Popular (O Curso de Educadores é inaugurado amanhã com a presença do subsecretário de Educação, 1953). O curso, aberto a professores, regentes e a pessoas interessadas, estava organizado em "duas fases», uma primeira, incluía a apresentação de dúvidas e a orientação "psicopedagógica para tarefas educativas de adultos» e estoutra, constituída por «liçóes práticas de leitura, escrita e aritmética iniciais para adultos» (Inaugurou-se ontem com uma sessão solene um Curso de Educadores de Adultos em Coimbra, 1953). Pelas páginas dos jornais regionais foi possível, ainda, elencar as missóes culturais realizadas no distrito de Coimbra, bem como a calendarização e realização de sessões de cinema no âmbito da Campanha Nacional de Educaçáo de Adultos. No cumprimento do legalmente estabelecido (1952, p. 1094) tomamos conhecimento, através das páginas da imprensa regional, da composição e tomada de posse da comissáo distrital, e das concelhias, de Coimbra.

Ao longo dos anos de 1953 e 1954, foram surgindo notícias dando conta da abertura de cursos de educação de adultos, em diferentes fábricas do concelho, nomeadamente, nas Fábricas Triunfo, na SIAC, fábrica de azulejos situada na estrada de Coselhas, na Lufapo, localizada na Pedrulha, n’ A Ideal, Lda., e em Taveiro, na firma Barbosa e Ca Lda. Os três cursos mistos das Fábricas Triunfo tiveram honras de inauguraçáo pública, em 1953 e, em 1954, já eram quatro cursos e as instalações foram mesmo visitadas por Veiga de Macedo, subsecretário de Estado. Permitimo-nos sublinhar este contributo das entidades patronais, dando corpo ao determinado no artigo $98^{\circ}$, fornecendo instalaçóes para o funcionamento dos cursos de educação de adultos, provavelmente, porque teriam "mais de vinte assalariados com menos de 35 anos de idade e sem habilitação da $3^{\text {a }}$ classe do ensino primário» (1952, p. 1091). Já a dimensão e o volume das notícias dedicadas às Fábricas Triunfo, não será alheio o facto de o seu director e proprietário, Sousa Machado, ser, simultaneamente, deputado «da nação», numa ilustração clara, da proximidade entre o poder político, as elites locais e os interesses económicos, no período do Estado Novo. Ao nível associativo, destaque para a Associação de Artistas de Coimbra, onde se realizaram diferentes cursos de educação de adultos.

A colaboração da Igreja também foi explícita e empenhada. Em Provisão contra o analfabetismo, considerando a iniciativa do governo como o «maior esforço feito na nossa terra contra uma das maiores vergonhas da nossa história». Considerava, a Provisão, que ler, escrever e contar significava ter «sentidos e faculdades novas», pelo que se recomendava aos párocos «ajudar e animar», "dando o melhor do seu esforço, entusiasta e perseverante» e, no mínimo, deveriam «tornar conhecida do povo» a legislação. A própria provisão deveria 
ser «lida e comentada à estação da Missa Paroquial em um ou mais Domingos» (Provisão contra o analfabetismo, 1953).

Por último, consultámos o jornal $A$ Campanha, órgão da Campanha Nacional de Educação de Adultos, periódico quinzenal, mensal desde Março de 1954, publicada entre Outubro de 1953 e 1956, a que voltaremos mais à frente.

\section{O contexto internacional e o Plano de Educação Popular de combate ao analfabetismo}

As condições internas e externas no Portugal do pós-guerra despoletaram uma momentânea onda de esperança de democratização que conduziram mesmo, o Estado Novo, a tolerar a concorrência eleitoral e, no plano da política externa, assistiu-se a algumas hesitações, no que se refere ao posicionamento internacional de Portugal. Em 1948, Portugal foi membro fundador da Organização Europeia de Cooperação Económica (OECE, hoje, OCDE) e, contudo, recusou a ajuda, referente a 1948-1949, no âmbito do plano Marshall. Paralelamente, muito por força das condiçóes criadas pela nova ordem económica internacional, no plano interno, foi lançado o I Plano de Fomento, no quinquénio de 1953-1958, definindo prioridades e, ainda que traduzindo um «somatório de planos parciais», não deixou de constituir "um conjunto de investimentos públicos» aos quais foram alocados «recursos financeiros» (Nunes \& Brito, 1992).

Os «anos dourados» (Hobsbawm, 2002 [1996]) registaram, concomitantemente com o crescimento exponencial da oferta educativa, uma «explosão» da educação de adultos. Sob o patrocínio da Unesco, em 1949, ocorreu, em Elseneur (Dinamarca), a primeira das conferências internacionais de educação de adultos, conferindo-lhe uma dimensão planetária e destacando a importância dos organismos internacionais no seu desenvolvimento (Canário, 2008). Nessa conferência, o Director-geral da Organização das Naçóes Unidas (ONU), Torres Bodet, condenou aqueles que ainda consideravam a instrução como perigosa e esclareceu que "o fim da educação de adultos é a valorização do indivíduo integrado na vida e progresso da colectividade. [...] Não se trata de ensinar ao adulto esta ou aquela arte, esta ou aquela ciência mas de instruí-lo numa disciplina mais vasta de que só ingenuamente podemos supô-lo conhecedor: a própria vida» (Barcoso, 2002, pp. 323-324). Saber ler podia, afinal, ensinar a tornar a vida melhor. A educação de adultos correspondeu, neste período, a uma oferta educativa de segunda oportunidade, conquistando especial relevância as actividades educativas de alfabetização.

Apesar de, aparentemente, Portugal se ter conseguido manter «razoavelmente à margem da ordem económica internacional» (Nunes \& Brito, 1992, p. 328) até à década de sessenta, a verdade é que integrar a OECE, mais tarde OCDE, se traduziu numa abertura ao exterior que implicou uma crescente exposição, do ponto de vista económico e educativo, e o risco, tanto mais embaraçoso face à natureza do regime, de ver expostas as assimetrias entre Portugal e o resto dos países europeus, mesmo em relação aos denominados países do Sul da Europa, como se verá na década de sessenta. Recorde-se que à época, Portugal e a Turquia, eram os países com maior taxa de analfabetismo e com menor duração da escolaridade obrigatória.

Foi neste contexto que o Ministério da Educação Nacional publicou os diplomas legais que enformaram o Plano de Educação Popular, o decreto-lei n.o 38 968, que «reforça 
o princípio da obrigatoriedade do ensino primário elementar, reorganiza a assistência escolar, cria os cursos educaçáo de adultos e promove uma campanha nacional contra o analfabetismo" (1952, p. 1067), e o decreto-lei n. 38969 que regulamenta o disposto no anterior, dividido em sete capítulos, os primeiros, sobre a obrigatoriedade de ensino, o recenseamento escolar - com a particularidade de implicar professores, cuja acção tinha peso na sua avaliaçáo profissional - e a assistência escolar, que ia no sentido de reforçar o apoio aos alunos, e às alunas carenciados. $\mathrm{O}$ capítulo IV tratava do reforço das medidas de obrigatoriedade escolar que iam desde multas à suspensão do abono de família até mesmo à impossibilidade de ingressar em serviços do Estado. Aos adultos sem a escolaridade de três anos ficava vedada a possibilidade de obterem a carta de conduçáo, autorização para emigrar e os mancebos, incorporados depois de Janeiro de 1954, não podiam passar à disponibilidade sem a escolaridade obrigatória. Os cursos de educação de adultos (capítulo V) funcionavam 1 de Novembro a 31 de Maio, enquanto a Campanha Nacional de Educaçáo de Adultos (capítulo VI) com vigência prevista, de Janeiro de 1953 a 31 de Dezembro de 1954 - período esse que, em face de um propalado sucesso, viria a ser dilatado por mais dois anos - e se destinava a adolescentes e adultos entre os 14 e os 35 anos. O capítulo final abordava a «organização da Direcção-Geral do Ensino Primário e das direcçôes dos distritos escolares» (1952, p. 1094).

O diploma, aqui genericamente resumido, aproximava-se da noção de capital humano, estabelecendo uma relação quase directa entre nível de escolaridade e produtividade, filiandose na ideologia, comummente sustentada na OCDE na década de sessenta, designada de ocedeísmo. Bem elucidada nesta passagem:

Não podem, de resto, esquecer-se as relaçóes de esta dependência entre a produtividade do trabalho e a difusão do ensino. É indiscutível que uma boa instrução traz grandes vantagens ao trabalhador: desenvolve as faculdades de atenção, apura-lhe o espírito de observação, estimula a sua actividade mental, torna-o mais confiante, mais inteligente, mais apto a aperfeiçoar-se no exercício da profissão. Ela constitui, por isso mesmo, factor importante na produção de riqueza (1952, p. 1079).

Contudo, ao contrário do que um olhar menos atento poderia supor, o Estado Novo não cedeu o passo aos paladinos do capitalismo, o legislador vai ter o cuidado de matizar as preocupaçóes mais economicistas compaginadas com as preocupaçóes de formação do homem sustentadas pela Unesco, com o substrato ideológico do regime. Assinalemos paralelamente, a propósito da Campanha Nacional de Educação de Adultos, a procura de uma certa legitimidade científica:

O método geral para uma primeira fase de educação de adultos mais defendido por especialistas da cultura popular é o da campanha contra o analfabetismo. Este será o método adoptado através de uma Campanha Nacional de Educação de Adultos. Com a designaçáo escolhida pretende-se significar que não se procura apenas transmitir aos analfabetos os rudimentos da leitura, da escrita e do cálculo, mas ainda contribuir para a educaçáo geral do nosso povo. Por isso se consagra também como objectivo da campanha a divulgação de noçôes de educação moral e cívica, organização corporativa, previdência social, segurança no trabalho, higiene e defesa da saúde, agricultura e pecuária (1952, p. 1080). 
O quadro de controlo e redução que marcou quase toda a política educativa do Estado Novo sobressai na análise realizada ao Plano de Educaçáo Popular. O controlo ideológico que detectamos no diploma legal, visível na preocupaçáo com a «divulgação de noçóes de educação moral e cívica, organização corporativa», por exemplo, estava bem presente no órgão oficial da Campanha e nas actividades culturais desenvolvidas. Emergia em aspectos como a constituiçáo de bibliotecas e na consequente selecção dos livros, em questóes gerais de educação e higiene mas também em páginas dedicadas aos castelos de Portugal, à promoção regionalista das províncias, como é exemplo Trás-os-Montes, ou na apresentação de figuras de significativa importância na imagética histórica nacionalista, como é o caso do Infante D. Henrique. Quanto à redução, dimensão integrante da preocupação com o efectivo cumprimento da alfabetizaçáo, ela respirava-se no limitado programa do ensino primário para adultos (Despacho de 27 de Março de 1953, do subsecretário de Estado da Educação, 1953) e na manutenção de uma escolaridade obrigatória de três anos.

\section{As representaçóes dos corpos, docente e discente, da Escola do Magistério Primário}

Inadaptado (Escola e Biblioteca, 1953) ou ignorante (Torgal, 1953) são epítetos que classificam o analfabeto, reconhecendo-se que não saber ler é, no mundo moderno, uma incapacidade. Numa abordagem ao facto social, a leitura é percebida como uma competência básica - sem ela ninguém consegue auto-educar-se - da modernidade e o facto de alguém não a possuir era entendido como uma ameaça para o seu lugar na sociedade:

Qual a posição dum analfabeto perante a sociedade? Que progresso conseguirá na vida? Que valor poderá emanar do seu trabalho? É preciso não esquecer que os autoeducadores são raros, e os que existem foram beber à Escola Primária um mínimo de noçôes elucidativas, que servirão de base a toda a aprendizagem (Luís \& Graciette, 1953).

Já a análise do problema enquanto fenómeno social, o analfabetismo, é identificado com a ignorância (Não consintas analfabetos no teu meio, 1953), considerado um obstáculo ao progresso (Luís \& Graciette, 1953) e visto como uma ignomínia social (Gaspar, Corajosa Campanha, 1953).

A reflexão sobre as causas do analfabetismo também assaltou alunos e alunas, bem como professores, da Escola do Magistério Primário de Coimbra. A responsabilização da família, pela simples demissão (Oliveira R., 1953) ou pelo recurso ao trabalho infantil, a distribuição da população pelo território nacional, a Educação Nacional - seja pela deficiente rede escolar ou pela natureza da escola primária (Oliveira A. , 1953) - e o atraso da formação social portuguesa em atingir a modernidade, aqui entendida como a passagem do mundo rural e agrícola ao industrial e urbanizado, são factores apontados como causas do analfabetismo. A este propósito escreveria José Maria Gaspar, ao tempo professor da Escola:

[...] as complexas causas originais do analfabetismo nacional: a dispersão das populaçôes rurais e o alheamento das urbanas; a ambição dos pais pela utilização prematura do trabalho dos filhos; uma ou outra falta ou má localizaçáo dos edifícios escolares e a rotineira inércia de certos meios ainda mecanizados em multi-secular ignorância (Gaspar, Rumo ao Futuro, 1953). 
Como sublinhava o subsecretário de Estado da Educação, o «pai» da Campanha, Henrique Veiga de Macedo, aquando da conferência de imprensa do aniversário do primeiro ano da Campanha Nacional de Educação de Adultos, o analfabetismo encerrava em si as suas condiçôes de reprodução e para salvar os filhos, tornava-se imperioso educar os pais:

O analfabeto não tem a noção da vantagem do ensino e entende, na sua visão deformada das coisas, que os filhos não carecem, para as lutas da vida, de quaisquer habilitaçóes literárias. Esta triste realidade torna ainda mais premente a necessidade de fazer alguma coisa para educar os analfabetos, os quais irão, por experiência vivida, convencendo-se do interesse prático em instruir os filhos.

[...] pela própria natureza das causas do analfabetismo entre nós, e em especial do facto de, mormente nos meios rurais, o nosso povo, pelas condiçóes de vida, pelo regime do seu trabalho e até pela força do hábito e da rotina, não sentia a necessidade de aprender (Macedo, 1953).

Estribados nestes conceitos, discentes e docentes, analisaram o Plano de Educação Popular pela descrição ou discussão da legislação ou pela associação ao combate ao analfabetismo por via da escolaridade obrigatória, destacando-se os elogios ao governo e o sublinhar da imagem de Portugal no estrangeiro. Como escrevia DCR:

Os esforços que o Governo tem enviado para acabar com o analfabetismo, consumados, o ano passado, com o notável decreto da obrigatoriedade de ensino, estão a merecer da imprensa estrangeira os maiores encómios. Ela é unânime nos aplausos e uma vez mais a figura do grande paladino do nosso regresso à política internacional e da nossa auto-bastança, teve a projecção devida. [...]

Outros órgãos da imprensa se têm referido ao notabilíssimo diploma que declara guerra sem tréguas ao analfabetismo. Nos periódicos do país os louvores são gerais e em tudo transparece o enorme desejo de se acabar com tão deplorável aspecto da vida nacional (DCR, 1953).

Esta preocupação do elogio da acção governativa não se limita à legitimação internacional, mas buscou, ainda, uma legitimação histórica, por contraponto com a Primeira República, destacando a contradição entre a produção legislativa e prática social do regime republicano e a acção efectiva do Estado Novo. Atente-se nesta passagem e não deixemos de sublinhar que a Primeira República terminara vinte e sete anos antes:

Que interessa, na verdade, que a lei previsse cursos nocturnos, missóes escolares, cursos dominicais e outros análogos para a extinção do analfabetismo, em ambos os sexos, naquelas localidades onde as circunstâncias o exigissem (artigo 31 ${ }^{\circ}$ da Lei 1.911) e que prescrevesse que às Juntas Escolares compete estabelecer cursos nocturnos, cursos dominicais e cátedras ambulantes (Decreto no 6.137, de 21 de Setembro de 1919), se, passados anos, se haveria de verificar que os índices do analfabetismo continuavam no mesmo nível de 1910 ?

A existência de 2.916.600 iletrados deveria constituir, e, constitui, séria preocupação para os responsáveis. Daí as providências legislativas sobre instrução obrigatória, cujo êxito, no fim de um ano de vigência, fica a assinalar a capacidade realizadora do regime 
nos domínios da educação. Daí o alargamento da assistência escolar, através de uma legislação prática e simples já em execução com os mais auspiciosos frutos. Daí o ter-se reforçado o princípio da obrigatoriedade do ensino, numa nova e mais firme orientaçáo imposta pela própria natureza das causas do analfabetismo entre nós, e em especial do facto de, mormente nos meios rurais, o nosso povo, pelas condiçóes de vida, pelo regime do seu trabalho e até pela força do hábito e da rotina, náo sentia a necessidade de aprender (1º Aniversário da Campanha de Educação de Adultos, 1953).

Nas páginas do Rumo surgiram sucessivos apelos para que os analfabetos agissem para pôr fim à sua situação individual e à vergonha de todos (Torgal, 1953), paralelamente àqueloutros que sublinhavam a necessidade de que só inferiorizando socialmente o analfabeto, para que este se convencesse da sua inaptidáo em face da "moderna vida civilizada» (Gaspar, Rumo ao Futuro, 1953), se combateria efectivamente o analfabetismo. Estes posicionamentos emergiram compaginados com um forte discurso de mobilização das camadas letradas do país, em prol da Pátria, independentemente das camadas ou grupos sociais de pertença (Vieira, 1953), ainda que a sociedade seja ordenada e os seus membros tenham funçóes determinadas para organizar o entusiasmo participativo, sobressaindo o destaque simbólico colocado no papel do professor:

Há, primeiro, quem, por dever trabalhe no especial empenho do governo. Há, depois, quem devotadamente se esforce na cruzada geral da Nação.

Uns - estadistas, funcionários e professores - lançam mão dos seus valores e influência para superiormente dinamizarem condiçóes docentes: estruturam a campanha e nela se mantêm permanentemente ao parapeito.

Outros - dirigentes, patróes e encarregados de serviços - actuam nos respectivos meios e associaçôes, para directamente fomentarem o interesse discente: movimentam a orgânica e nela se agitam ordenadamente em activa disciplina construtiva.

[...] Mas o essencial nesta luta é sem dúvida o professor, com os elementos pedagógicos de que possa dispor (Gaspar, Rumo ao Futuro, 1953).

O incentivo ao envolvimento da população letrada foi acompanhada da mobilização de meios cuja discussão também é feita no âmbito da Escola do Magistério Primário de Coimbra. Particular atenção mereceu o cinema, apresentado como um grande factor de educação e um veículo capaz de coordenar vontades para esta luta que nos toca a todos, em particular para chegar às pessoas de letras gordas. Nas páginas do Rumo, o aluno-mestre Dinis dos Ramos resumiu assim as iniciativas nacionais do que considerou ser cinema educacional:

No curto espaço de seis meses realizar-se-ão 20 pequenos filmes que assim vão representar a contribuição cinematográfica alvitrada nos decretos 38.968 e 39.969. Com o patrocínio do Ministério da Educação Nacional e sob a proficiente direcção e orientaçáo do Sr. Dr. Afonso Botelho, nos estúdios da Lisboa-Filme, já se iniciaram os trabalhos, cuja realizaçáo pertence a Orlando Vitorino, Ricardo Malheiro e Filipe Solms - conhecidos nomes dos nossos estúdios. As películas irão de 73 a 300 metros e igualmente seráo tiradas cópias de $16 \mathrm{~mm}$. que serão distribuídas afim de proporcionarem espectáculos às mais afastadas aldeias por meio do cinema ambulante. Estamos certos de que as películas cuja moralidade e intenção não carecem de adjectivos, percorrerão Portugal de lés-a-lés. 
Neste momento já foram rodados os filmes «Fui ao Jardim Celeste», realização de Orlando Vitorino e Azinhal Abelho e «Labirinto», realização de Ricardo Malheiros e João Mendes. Nesta película nota-se a presença de Humberto Madeira, o «Milionário do Riso» que interpreta no celulóide a figura dum magala e a sua condiçáo de iletrado. O conhecido artista Vasco Santana incarnará um «Zé Analfabeto» que irá à teia todas as semanas contar as suas desditas por mor de não saber ler, numa série de complementos, a realizar por Filipe Solms e Carlos Marques.

As histórias, umas vezes narradas por Artur Agostinho, Raul Feio ou D. João da Câmara, locutores da nossa Estaçáo Oficial, apesar da sua finalidade educativa, serão, no entanto, de molde a interessar as plateias (Ramos, 1953).

A Campanha Nacional de Educação de Adultos foi dirigida a pessoas de diferentes proveniências sociais, socialmente inferiorizados pela ausência de posse de escolarização, traduzindo uma preocupação de todos, isto é, nacional. Ao longo da análise dos discursos detectamos uma evolução, ainda que ténue, por um lado, no papel atribuído à escola, tendo surgido discursos que reconheciam que a sua frequência podia provocar modificaçóes na escala social e ajudar os indivíduos e os grupos sociais a ascenderem socialmente e, por outro, a adopção de um discurso próximo do ocedeísmo, afirmando-se que a educação de adultos pode traduzir um significativo "aumento do capital humano na nação" e que a redução de analfabetos contribuiria para o aumento da produtividade ( $1^{\circ}$ Aniversário da Campanha de Educação de Adultos, 1953). Evolução sempre compaginada com o elogio do governo e das virtudes do Estado Novo e de Salazar (Aluno-mestre, 1953).

Encerremos o nosso breve contributo para a compreensão do Plano de Educação Popular da década de cinquenta com as palavras de Hermínia da Silva Pinto (Pinto, 1953), então recém-diplomada do curso de educação de adultos, que, de algum modo, faz jus ao controlo ideológico do Estado Novo na educação, reproduzindo muito do discurso oficial mas, simultaneamente, traduz a satisfação e, quiçá, o orgulho em si própria, pelo esforço desenvolvido, aproveitando uma segunda oportunidade quando a primeira tardou em chegar:

\footnotetext{
Pessoas mais velhas e mais novas do que eu fizeram o mesmo e nenhuma está arrependida. Estão arrependidas outras que podiam fazer o mesmo e não fizeram porque não quiseram. Por isso eu agora convido a todos os que náo sabem ler ou que náo têm o exame de instrução primária a aceitarem o benefício do Estado e irem aos Cursos de Adultos, para ficarem também com o benefício da escola.

Sem isso, nem podem ser alguém e ainda envergonham os portugueses diante dos outros povos.

Por mim estou muito contente por ter feito o meu exame e hei-de dizer a toda a gente, que possa, que faça o mesmo para Portugal não ficar atrás das outras nações.
}

\section{A Campanha contra o analfabetismo... Um importante contributo}

Uma referência para o livro publicado pela Coimbra Editora, em 1953, da autoria de Francisco de Sousa Loureiro e José Maria Gaspar, respectivamente, director e professor da Escola do Magistério Primário de Coimbra, intitulado Educação do Adulto Iletrado, com 
o subtítulo orientação psico-pedagógica e didáctica. Considerado, desde logo, pela imprensa da época como um importante contributo, tanto mais que título e subtítulo eram «muito sugestivos principalmente no momento que passa, em que está em causa e combate, $\grave{a}$ outrance, do analfabetismo. Patriótica Cruzada! Redenção bem almejada!» (Donato, 1953).

O livro parece ter constituído o resultado do desenvolvimento dos cursos de educadores de adultos ou ser o trabalho de reflexão e estudo para a realizaçáo dos cursos de educadores de adultos tal é a semelhança entre o conteúdo desses cursos e o do livro. Efectivamente, a relevância deste contributo está, para além do mérito que o seu conteúdo possa conter do ponto de vista científico - hoje ou à época da sua publicação -, no facto de ser único, na verdade não temos conhecimento de qualquer outra publicaçáo no género. De resto este aspecto foi assinalado na altura pelos seus autores que no prefácio afirmam não conhecer "literatura semelhante que tenha aparecido no mercado» (Loureiro \& Gaspar, s. d. [1953]), o que terá constituído uma dificuldade acrescida que, de resto, foi registada pela própria imprensa, aqui nas palavras de Ernesto Donato:

Os dois nomes que nos apresentam este proveitoso contributo na Educação do adulto iletrado, são já bem conhecidos e considerados, e bem o garantem, não diremos "Magisterdixit" - servindo-nos da locução usada na Idade Média, pelos Escolásticos, - pois os seus respectivos Autores não póem essa veleidade naquilo de que tratam em 142 páginas; - não obstante não conhecerem a literatura semelhante, que tenha aparecido no mercado, pelo menos confessam: lutamos com dificuldades compreensiveis, que não reconhecemos não inteiramente verificadas (Donato, 1953).

A obra surge dividida em oito capítulos, abrindo com a diferenciação entre a criança e o adulto (capítulo I), que encerra com sugestóes para a organização das turmas de adultos, seguindo-se-lhe uma reflexão sobre o que significa ser professor de crianças ou de adultos (capítulo II). No terceiro capítulo os autores discutiram a finalidade educativa, mediata e imediata, contrapondo a infância ao adulto, os programas, a sociabilidade escolar, as questóes dos recreios, duração e repartição da aprendizagem, encerrando com a questão dos exames, enquanto verificação do saber. No seguinte discutem-se generalidades metodológicas e didácticas para adultos e didáctica específica para adultos contemplando, aqui, problemas como a actividade, a concretizaçáo, a oralidade, os interesses, o material de ensino e a orientação. Os capítulos V a VII abordam as questóes da metodologia e da processologia do ensino da leitura, da escrita e da aritmética, respectivamente. Um último capítulo, o VIII, constitui uma "Nota Final» onde os autores começam por sublinhar que a «a luta contra o analfabetismo", a par dos problemas psicológicos e sociais encerra, também, problemas económicos. Nesta reflexão final sobressai este permanente balançar entre as preocupaçóes do capital humano e a formação global do homem. Discutindo as limitaçóes de uma Campanha, espaldando-se nas propostas da Unesco, os autores, enjeitam como seu objectivo, colocar um fim no analfabetismo absoluto para criar o analfabetismo relativo. Não bastava, em seu entender, ensinar a ler, escrever e contar, era necessário capacitar o homem para a sua profissão mas de modo a criar-lhe «curiosidade intelectual» e "hábitos de pensamento, excitando-lhe o prazer de saber mais e saber melhor e predispondo-o à consciente contemplaçáo de panoramas, horizontes e projectos mentais sucessivamente mais largos e mais elevados» (Loureiro \& Gaspar, s. d. [1953], pp. 130-131). Afinal pretendiam que esse fosse o papel dos «cursos de educação de adultos: ensinar, agitar os meios ignorantes 
e semear por eles ânsias de elevação humana, com nervuras de intelectualidade capazes de elevar, sem azedar, toda a massa nacional (Loureiro \& Gaspar, s. d. [1953], p. 131).

\section{Nota final}

Não foi nosso desejo avaliar os resultados do Plano de Educação Popular, em geral, ou da Campanha Nacional de Educação de Adultos, antes tão só, dar visibilidade e compreender a sua recepçáo pelos discentes e docentes do ensino normal primário em Coimbra e qual o contributo que a Escola do Magistério Primário de Coimbra para o seu desenvolvimento, no momento em que este foi expressamente solicitado, por responsáveis políticos nacionais. Globalmente, diríamos, a Escola terá dado corpo ao que lhe foi solicitado. Realizou os cursos de educadores de adultos, preparando recursos humanos para o desenvolvimento da Campanha e a realização dos cursos de educação de adultos, e contribuiu com reflexão própria sobre a temática e que esteve na génese da publicação do único livro, que tenhamos conhecimento, publicado sobre o assunto. Finalmente, e em relação ao estudo que realizámos, merece destaque o próprio impacto que a Campanha e os cursos de adultos terão tido na cidade e no distrito de Coimbra, nomeadamente, no envolvimento da sociedade - Igreja, empresas, movimento associativo e corporativo -, no volume de iniciativas que concitou, mesmo ao nível do poder central e local, e no seu impacto na imprensa regional. Naturalmente que se justifica uma outra análise desta vertente e de outras temáticas relacionadas com o Plano de Educação Popular, a que por certo voltaremos, mas que não cabia aqui e que não eram o nosso objectivo.

\section{Referências Bibliográficas}

10 Aniversário da Campanha de Educação de Adultos. (15 de Novembro de 1953). Rumo, Quinzenário dos alunos da Escola do Magistério Primário de Coimbra.

Aluno-mestre, n. 2. (15 de Fevereiro de 1953). Trabalho para o futuro. Rumo, Quinzenário dos alunos da Escola do Magistério Primário de Coimbra.

As Escolas do Magistério Primário de Coimbra e a formação de Educadores de Adultos. (Agosto/Setembro de 1954). A Campanha, p. vi.

Barcoso, C. (2002). O Zé Analfabeto no cinema. Lisboa: Educa.

Canário, R. (2008). Educação de adultos. Um campo, uma problemática. Lisboa: Educa.

Candeias, A., Paz, A. L. \& Rocha, M. (2004). Alfabetização e Escola em Portugal nos Séculos XIX e XX. Os Censos $e$ as Estatísticas. Lisboa: Fundação Calouste Gulbenkian.

DCR. (15 de Fevereiro de 1953). Pela imprensa estrangeira. Rumo, Quinzenário dos alunos da Escola do Magistério Primário de Coimbra.

Decreto-Lei n. 38 968. (27 de Outubro de 1952). Diário de Governo. I Série - n. ${ }^{\circ} 241$, pp. 1067-1084.

Decreto-Lei n. 38 969. (27 de Outubro de 1952). Diário do Governo. I Série - Número 241 , pp. 1084-1095.

Despacho de 27 de Março de 1953, do subsecretário de Estado da Educação. (4 de Abril de 1953). Diário de Governo. II Série.

Donato, E. (12 de Dezembro de 1953). A Campanha contra o analfabetismo... Um importante contributo. $O$ Despertar.

Escola e Biblioteca. (15 de Janeiro de 1953). Rumo, Quinzenário dos alunos da Escola do Magistério Primário de Coimbra.

Fernandes, R. (1993). Marcos do Processo Histórico de Alfabetizaçāo de Adultos em Portugal. Colóquio Educação e Sociedade n. ${ }^{\circ}$, pp. 115-144. 
Gaspar, J. M. (15 de Dezembro de 1953). Corajosa Campanha. Rumo, Quinzenário dos alunos da Escola do Magistério Primário de Coimbra.

Gaspar, J. M. (15 de Junho de 1953). Rumo ao Futuro. Rumo, Quinzenário dos alunos da Escola do Magistério Primário de Coimbra.

Grácio, R. (1981). Ensino Primário e Analfabetismo. In J. Serrão, Dicionário de História de Portugal (pp. $392-$ 397). Porto: Portugalense.

Hobsbawm, E. (2002 [1996]). A Era dos Extremos. História Breve do Século XX 1914-1991. Lisboa: Editorial Presença.

Inaugurou-se ontem com uma sessão solene um Curso de Educadores de Adultos em Coimbra. (4 de Dezembro de 1953). Diário de Coimbra.

Lima, L. (2006). Educação não escolar de adultos. Braga: Universidade do Minho/Unidade de Educação de Adultos.

Loureiro, F. S., \& Gaspar, J. M. (s. d. [1953]). Educação do adulto iletrado (orientação psico-pedagógica e didáctica). Coimbra: Coimbra Editora, Limitada.

Luís, \& Graciette. (15 de Maio de 1953). Ensinar e examinar. Exames. Rumo, Quinzenário dos alunos da Escola do Magistério Primário de Coimbra.

Macedo, E. V. (15 de Novembro de 1953). 1 Aniversário da Campanha de Educação de Adultos. Rumo, Quinzenário dos alunos da Escola do Magistério Primário de Coimbra.

Não consintas analfabetos no teu meio. (1 de Junho de 1953). Rumo, Quinzenário dos alunos da Escola do Magistério Primário de Coimbra.

Nunes, A. B., \& Brito, J. M. (1992). Política económica, industrialização e crescimento. In F. Rosas, Portugal e o Estado Novo (1930-1960) (pp. 306-351). Lisboa: Editorial Presença.

O Curso de Educadores é inaugurado amanhã com a presença do subsecretário de Educação. (1 de Dezembro de 1953). Diário de Coimbra.

Oliveira, A. (15 de Junho de 1953). Campanha Nacional. Rumo, Quinzenário dos alunos da Escola do Magistério Primário de Coimbra.

Oliveira, R. (15 de Junho de 1953). Futuro melhor. Rumo, Quinzenário dos alunos da Escola do Magistério Primário de Coimbra.

Pinto, H. d. (15 de Dezembro de 1953). Palavras de uma adulta diplomada. Rumo, Quinzenário dos alunos da Escola do Magistério Primário de Coimbra.

Pires, M. A. (1990). O Plano de Educação Popular ou a legislação de 27 de Outubro de 1952 nos primeiros anos da sua execução. Revista Portuguesa de Pedagogia n. ${ }^{\circ} 24$, pp. 477-518.

Provisão contra o analfabetismo. (16 de Janeiro de 1953). Correio de Coimbra, p. 1 e ss.

Ramos, D. d. (1 de Julho de 1953). Cinema educacional. Rumo, Quinzenário dos alunos da Escola do Magistério Primário de Coimbra.

Torgal, G. R. (15 de Maio de 1953). Analfabeto. Rumo, Quinzenário dos alunos da Escola do Magistério Primário de Coimbra.

Vieira, M. B. (15 de Junho de 1953). O saber eleva o homem. Rumo, Quinzenário dos alunos da Escola do Magistério Primário de Coimbra. 
Série Documentos

Imprensa da Universidade de Coimbra

Coimbra University Press

2011

- U

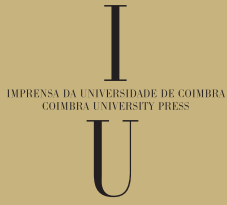

